\title{
Measuring Tourist's Characteristics and Preferences in Selecting A Destination: A Case of Labuan Bajo as A Priority Destination in Indonesia
}

\author{
Luh Yusni Wiarti ${ }^{1}$, Anom Hery Suasapha ${ }^{2}$, Ni Made Eka Mahadewi ${ }^{3}$, \\ Sukma Winarya Prabawa ${ }^{4}$, I.B Putra Negarayana ${ }^{5}$, Hanugerah Kristiono Liestiandre ${ }^{6}$ \\ \{yusni168@gmail.com ${ }^{1}$ \} \\ Sekolah Tinggi Pariwisata Nusa Dua Bali, Jl. Dharmawangsa, Benoa, Kec. Kuta Sel., Kabupaten \\ Badung, Bali, Indonesia ${ }^{123456}$
}

\begin{abstract}
This study aims to determine the characteristics and preferences of tourists who visit the priority destination Labuan Bajo. A quantitative approach research by Cross tabulation analysis is used to analyze the Primary data obtained from the survey of 240 tourists: 175 foreign tourists and 65 domestics. It is written based on the results of the research done by the student of Tourist Destination Study Program, of STP Nusa Dua Bali. The result shows that tourists' characteristics in geographic aspect is dominated by European, thereafter from the demographic aspect they are dominated by tourist in the age of 26-35 years old and mostly they are undergraduate tourist (bachelor level). From the Psychographic aspect shows that their length of stay are 4-5 days and their expenditure are about $>$ Rp.8.000.000. Although the icon of the destination is Komodo Dragon animal, but surprisingly the result shows that their favorite attraction and activity are not dominated by Komodo Island and to see the komodo, but dominated by the attraction of Padar Island, with diving/snorkeling and hiking/trekking around diving spot in Komodo national park as their major favorite activity during their stay in Labuan Bajo.
\end{abstract}

Keywords: Tourist's; Priority Destination

\section{Introduction}

Tourist behavior is the process and activities involved when people search for, choose, use, evaluate, and sort out service products that satisfy them [1]. Preference means choice, or something that is preferred by consumer [2]. This tourist behavior is strongly influenced by external factors: cultural and social as well as internal factors : personal and psychological [3]. In conclusion, to be effective and efficient in promotional activities and carry out right on target for tourism development, information about tourist behavior is absolutely needed. This is important because tourist behavior will influence all marketing activities done by stakeholders either promotion or selling tourism products.

Therefore it is very necessary to do a research related to characteristics and preferences of Tourist in Labuan Bajo as a priority destination in Indonesia, with the number of foreign tourists projection target of 500,000 pax with foreign exchange of 500 million USD by the Indonesian Ministry of Tourism. 


\section{Method}

Two hundreds (200) respondent were selected as the primary source of data for this research. Fourty (40) of those responden representing domestic tourist visiting Labuan Bajo, while the rest (160) representing the international tourist population visiting Labuan Bajo. Those responden were determined purposively, and on field, the surveyor selected them accidentally. Data were also collected from other primary source through interview and observation, while documentation done to collect data from secoundary source of data. Data collected were than analyzed descriptively utilizing qualitative approach, to determined the type of tourist movement inside the area of Labuan Bajo.

\section{Result and Discussion}

Preference is part of consumer behavior means something that is more desirable, a top choice, and a priority requirement. preference is an attitude that prefers things rather than other objects [4]. From a tourism point of view, tourist preferences arise from the desires and needs of tourists towards the tourism products offered in carrying out tourist trips. Etymologically, the characteristic is that are typical of something which is synonymous with the words character and nature [4]. The are 2 types of the tourists pictures : trip descriptor and tourist descriptor. In the tourist descriptor, characteristics contain three parts, namely socio-demographic (age, sex, level of education, and occupation), geographical (place of residence), and psychographics (social class, expenses during destination, life style, travel companion and how many times they visited a destination [5].

\subsection{Foreign tourist's characteristic and preferences in Labuan Bajo}

\section{Area of origin - length of stay - expenditure.}

Based on cross tabulation analysis, shows that all respondents from each Continent have two dominating groups, namely those who stay 1-3 days and 4-6 days. Tourists from America who stay 1 - 3 days are divided into 2 groups : those who have a total expenditure of under Rp.3,500,000 (58.3\% of the total American respondent ) and above Rp.5,000 .000 (41.7\% of the total American respondent). The European tourist respondents were dominated by two groups: respondents with a stay of 1 - 3 days and expenses below Rp.2,000,000 $(15.5 \%)$, and groups of respondents with a stay of 4-6 days with expenses above Rp. $6,500,000(25.2 \%)$. The case for tourists from the Asian Continent is the same as tourists from the Americas, they stay for $1-3$ days, they are divided into two groups : respondents with expenditure below Rp.5,000,000 (50\% of the total Asian respondents) and the respondent with expenditure of more than Rp.6,500,000 (50\% of the total Asian respondents).

\section{Area of Origin - Favorite activity - Favorite Attraction}

It shows that the favorite tourist attraction of diving / snorkeling does not always cause respondents to choose tourist attraction in the form of diving / snorkeling spots. Respondents who chose diving / snorkeling as a favorite tourist attraction have a focused distribution on three different tourist attractions, namely Rinca Island (18.3\% of the total respondents), Komodo Island (14.9\% of the total respondents), and others in the form of diving / snorkeling spots around the waters area between Komodo Island and Labuan Bajo (18.9\% of the total respondents). 


\section{Expenditures-Length of stay-Preferred Transportation}

Respondents who choose to walk compared to use other modes of transportation have an equal distribution in each group of total expenditure. Respondents with a total expenditure of Rp.5,000,000 - Rp.6,500,000 were dominated by respondents who chose to walk compared to use other modes of transportation. Respondents with the most common transportation (boats, private vehicles) mostly have a total expenditure of more than Rp.8,000,000. Judging from the length of stay of under 4 days and having an expenditure of more than Rp.8,000,000, surprisingly dominated by tourists who preferred walk compared to use other modes of transportation.

\subsection{Foreign Tourist's Characteristic and Preferences in Labuan Bajo}

\section{Age - Favorite Tourist Activitiy - Favorite Tourist Attraction.}

The result shows that all age groups in domestic tourist respondents have the same favorite tourist attraction : Padar Island. Respondents who chose hiking / trekking as favorite activity mostly have the same favorite tourist attraction : Padar Island (68.75\%). Respondents who chose seeing Komodo as favorite activity also dominated by favorite tourist attraction of Komodo Island (37.5\%).

\section{Travel Partner - Favorite Accomodation - referred Transportation.}

Domestic respondents who visit Labuan Bajo with family are dominated by respondents who have a preference for choosing a star hotel as favorite accommodation (45.4\%). These respondents use rental vehicles more often as a mode of transportation $(68.1 \%$ of). Judging from the group of respondents who visiting with friends, dominated by tourists who chose non-star hotels as favorite accommodations (42.8\%). This group of respondents preferred using public transportation.

\section{Conclusions}

Respondent characteristics of foreign tourists visiting Labuan Bajo are predominantly from the European Continent, while domestic tourists are mostly from the Jakarta City of Indonesia. Foreign tourists and domestic have similar characteristics in gender that is dominated by male, aged 26-35 years, have the same level of education (bachelor) and they are first timer in Labuan Bajo.

Respondents of foreign tourists and domestic have the same dominant preference in the way they search the information about Labuan Bajo that they are mostly prefer the internet as a source of information. Most of them manage their own travel, prefer to stay in star hotels, also eat and drink in restaurants.

Some different characteristics of domestic and international can be seen in some features such as :1) length of stay : 4-6 days stay (foreign) and $\leq 3$ days (domestic ); 2) expenditure : > Rp.8,000,000 (foreign ) and Rp.2,000,000-Rp .3,500,000 ( domestic) ; 3) travel partner : visiting with family / relatives (foreign ) and travel with friends (domestic); 4) favorite tourist attraction : Komodo Island (foreign) and Padar Island (domestic); 5) Airline Preferences : Wing Airs for foreigners and Batik Air for domestic; 6) Modes of Transportation chosen : car rental ( domestic) and foreigner prefer walk on foot during their stay in Labuan Bajo. 


\section{References}

[1] M. A. Morissan, Periklanan : Komunikasi Pemasaran Terpadu. Jakarta: Ramdina Prakarsa, 2007.

[2] U. Sumarwan and M. Simanjuntak, "Perception and Preference of Advertising Influence Purchase Intentions of Children,” vol. 5, no. 2, pp. 185-192, 2012.

[3] P. Kotler, Marketing Management: Analysis, Planing, Implementation and Control, 10th ed. International: Prentice Hall, 200AD.

[4] J. P. Chaplin, Kamus Lengkap Psikologi. P.T. Raja Grafika Persada, 2002.

[5] N. N. Menuh, "Karakteristik Wisatawan Backpacker Mancanegara dan Dampaknya Terhadap Perkembangan Pariwisata di Kuta, Bali," Universitas Udayana, 2015. 